Вісник Харківського національного університету імені В.Н. Каразіна Серія "Математика, прикладна математика і механіка"

Том 87,2018 , с. $61-68$

УДК 517.954
Visnyk of V.N.Karazin Kharkiv National University Ser. "Mathematics, Applied Mathematics and Mechanics"

Vol. 87, 2018, p. 61-68

DOI: $10.26565 / 2221-5646-2018-87-05$

\title{
Boundary-value problems in a layer for evolutionary pseudo-differential equations with integral conditions
}

\author{
A.A. Makarov ${ }^{1}$, D.A. Levkin ${ }^{2}$ \\ ${ }^{1}$ V.N. Karazin Kharkiv National University \\ 4, Svobody sqr., 61022, Kharkiv, Ukraine \\ ${ }^{2}$ Kharkiv Petro Vasylenko National Technical University of Agriculture, \\ 44, Alchevskih str., Kharkiv, Ukraine \\ natvasmak@ukr.net,valoi@i.ua
}

Boundary-value problems for evolutionary pseudo-differential equations with an integral condition are studied. Necessary and sufficient conditions of wellposedness are obtained for these problems in the Schwartz spaces. Existence of a well-posed boundary-value problem is proved for each evolutionary pseudodifferential equation.

Keywords: pseudo-differential equations; boundary-value problem; Fourier transform; Schwartz space.

Макаров О.А., Левкін Д.А. Крайова задача в шарі для еволюційних псевдодиференціальних рівнянь 3 інтегральною умовою. Розглядається крайова задача для еволюційних псевдодиференціальних рівнянь з інтегральною умовою. Одержано умов коректності цієї задачі у просторах Л. Шварца, а також доведено існування коректної крайової задачі для будь-якого еволюційного псевдодиференціального рівняння.

Ключові слова: псевдодиференціальні рівняння; крайова задача; перетворення Фурьє, простір Шварца.

Макаров А.А., Левкин Д.А. Краевая задача в слое для эволюционных псевдодифференциальных уравнений с интегральным условием. Рассматривается краевая задача для эволюционных псевдодифференциальных уравнений с интегральным условием. Получены условия корректности этой задачи в пространствах Л. Шварца, а также доказано существование корректной краевой задачи для любого еволюционного псевдодифференциального уравнения.

Ключевые слова: псевдодифференциальные уравнения; краевая задача; преобразование Фурье; пространство Шварца.

2010 Mathematics Subject Classification: 35S10.

\section{Introduction}

Numerous papers are dedicated to nonlocal boundary-value problems for differential and pseudo-differential equations. In monograph [1], existing results are

(C) A. A. Makarov, D. A. Levkin, 2018 
reviewed in details. In papers [2, 3, 4], a two-point boundary-value problem for differential and pseudo-differential equations was studied, and necessary and sufficient conditions of well-posedness were obtained for this problem in various spaces of functions. Moreover, therein, existence of well-posed boundary-value problem was proved for a linear system of differential equations with constant coefficients. In paper [5], these results were extended to multilayer under an additional continuity condition (transmission condition). In the present paper, boundary-value problems for evolutionary pseudo-differential equations with integral conditions are studied. Necessary and sufficient conditions of well-posedness are obtained for this problem in the Schwartz spaces. Existence of a well-posed boundary-value problem is proved for each evolutionary pseudo-differential equation.

\section{Main part}

Consider the following boundary-value problems

$$
\begin{array}{ll}
\frac{\partial u(x, t)}{\partial t}=A\left(t, \frac{\partial}{\partial x}\right) u(x, t), & x \in \mathbb{R}^{n}, t \in[0, T], \\
\int_{0}^{T} B\left(t, \frac{\partial}{\partial x}\right) u(x, t) d \mu(t)=\varphi(x), & x \in \mathbb{R}^{n},
\end{array}
$$

and

$$
\begin{array}{ll}
\frac{\partial u(x, t)}{\partial t}=A\left(t, \frac{\partial}{\partial x}\right) u(x, t)+f(x, t), & x \in \mathbb{R}^{n}, t \in[0, T], \\
\int_{0}^{T} B\left(t, \frac{\partial}{\partial x}\right) u(x, t) d \mu(t)=0, & x \in \mathbb{R}^{n} .
\end{array}
$$

Here $A\left(t, \frac{\partial}{\partial x}\right)$ and $B\left(t, \frac{\partial}{\partial x}\right)$ are pseudo-differential operators with symbols belonging to the space of infinitely differentiable functions with power growth $C_{-\infty}^{\infty}$ (see [6]), $\mu(t)$ is a function of bounded variation.

Definition 1 Problem (1), (2) is said to be well posed from $S$ to $C^{1}([0, T], S)$ if for any function $\varphi \in S$ there exists a unique solution $u \in C^{1}([0, T], S)$ to this problem, and this solution depends continuously on $\varphi$ in appropriate topology.

Definition 2 Problem (3), (4) is said to be well posed from $C([0, T], S)$ to $C^{1}([0, T], S)$ if for any function $f \in C([0, T], S)$ there exists a unique solution $u \in C^{1}([0, T], S)$ to this problem, and this solution depends continuously on $f$ in appropriate topology.

Applying the Fourier transform with respect to space variables, we get the dual boundary-value problems

$$
\frac{\partial \widetilde{u}(x, t)}{\partial t}=A(t, s) \widetilde{u}(s, t), \quad s \in \mathbb{R}^{n}, t \in[0, T],
$$




$$
\int_{0}^{T} B(t, s) \widetilde{u}(s, t) d \mu(t)=\widetilde{\varphi}(s), \quad s \in \mathbb{R}^{n}
$$

and

$$
\begin{array}{ll}
\frac{\partial \widetilde{u}(s, t)}{\partial t}=A(t, s) \widetilde{u}(s, t)+\widetilde{f}(s, t), & s \in \mathbb{R}^{n}, t \in[0, T], \\
\int_{0}^{T} B(t, s) \widetilde{u}(s, t) d \mu(t)=0, & s \in \mathbb{R}^{n},
\end{array}
$$

where the Fourier transforms $\widetilde{u}, \widetilde{\varphi}$, and $\widetilde{f}$ also belong to $S$ for any $t \in[0, T]$. The function

$$
\widetilde{u}(s, t)=\psi(s) \exp \left(\int_{0}^{t} A(\tau, s) d \tau\right)
$$

is the solution to equation (5), where $\psi$ is an arbitrary function. By substituting this formula into equation (6), we obtain

$$
\psi(s) \int_{0}^{T} B(t, s) \exp \left(\int_{0}^{t} A(\tau, s) d \tau\right) d \mu(t)=\widetilde{\varphi}(s), \quad s \in R^{n} .
$$

The condition

$$
\Delta(s)=\int_{0}^{T} B(t, s) \exp \left(\int_{0}^{t} A(\tau, s) d \tau\right) d \mu(t) \neq 0, \quad s \in R^{n},
$$

is necessary for solvability of equation (9). Solution $\widetilde{u}$ belongs to $C^{1}([0, T], S)$ if and only if, for the resolving function

$$
Q(s, t)=\frac{1}{\Delta(s)} \exp \left(\int_{0}^{t} A(\tau, s) d \tau\right)
$$

we have $Q(\cdot, t) \in C_{-\infty}^{\infty}, t \in[0, T]$ (see [6]). Thus we have the following theorem.

Theorem 1 The problem (1), (2) is well-posed from $S$ to $C^{1}([0, T], S)$ if $Q(\cdot, t) \in$ $C_{-\infty}^{\infty}, t \in[0, T]$.

To solve problem (7), (8), we consider Green's function.

Definition 3 The function $G(s, t, \tau)$ is called Green's function of the problem (7), (8) if it satisfies the following conditions:

1) $G(s, t, \tau)$ is continuously differentiable on $[0, \tau) \cup(\tau, T], s \in \mathbb{R}^{n}, \tau \in[0, T]$;

2) $G(s, \tau+0, \tau)-D(s, \tau-0, \tau)=1$ on $t \in[0, \tau) \cup(\tau, T], s \in \mathbb{R}^{n}, \tau \in[0, T]$;

3) $\frac{\partial}{\partial t} G(s, t, \tau)=G(s, t, \tau)$ on $t \in[0, \tau) \cup(\tau, T], s \in \mathbb{R}^{n}, \tau \in[0, T]$;

4) $\int_{0}^{T} B(s, t) G(s, t, \tau) d \mu(t)=0, s \in \mathbb{R}^{n}, \tau \in[0, T]$. 
If Green's function exists, then there exists a unique solution to the problem (7), (8). Due to [7], this solution is defined by the formula

$$
\widetilde{u}(s, t)=\int_{0}^{T} G(s, t, \tau) \widetilde{f}(s, \tau) d \tau .
$$

Lemma 1 If $Q$ is the resolving function of problem (5), then

$$
G(s, t, \tau)= \begin{cases}\int_{0}^{\tau} B(\xi, s) Q(s, t-\tau+\xi) d \mu(\xi), & \tau \leq t, s \in \mathbb{R}^{n}, \\ -\int_{\tau}^{T} B(\xi, s) Q(s, t-\tau+\xi) d \mu(\xi), & \tau>t, s \in \mathbb{R}^{n},\end{cases}
$$

is Green's function of problem (7), (8).

Proof. Evidently, 1) holds. Let us prove 2). We have

$$
\begin{aligned}
G(s, \tau & +0, \tau)-G(s, \tau-0, \tau) \\
& =\int_{0}^{\tau} B(\xi, s) Q(s, \xi) d \mu(\xi)+\int_{\tau}^{T} B(\xi, s) Q(s, \xi) d \mu(\xi) \\
& =\int_{0}^{T} B(\xi, s) Q(s, \xi) d \mu(\xi) \\
& =\frac{1}{\Delta(s)} \int_{0}^{T} B(\xi, s) \exp \left(\int_{0}^{\xi} A(\tau, s) d \tau\right) d \mu(\xi)=1 .
\end{aligned}
$$

Condition 3) is true, because $Q$ satisfies equation (5). Now let us prove 4)

$$
\begin{aligned}
\int_{0}^{T} B(s, t) G(s, t, \tau) d \mu(t) & =-\int_{0}^{\tau} B(s, t) \int_{\tau}^{T} B(s, \xi) Q(s, t-\tau+\xi) d \mu(\xi) d \mu(t) \\
& +\int_{\tau}^{T} B(s, t) \int_{0}^{\tau} B(s, \xi) Q(s, t-\tau+\xi) d \mu(\xi) d \mu(t) \\
& =-\int_{\tau}^{T} \int_{0}^{\tau} B(s, t) B(s, \xi) Q(s, t-\tau+\xi) d \mu(\xi) d \mu(t) \\
& +\int_{\tau}^{T} \int_{0}^{\tau} B(s, t) B(s, \xi) Q(s, t-\tau+\xi) d \mu(\xi) d \mu(t)=0 .
\end{aligned}
$$

The lemma is proved.

Corollary 1 If problem (5), (6) is well-posed, then problem (7), (8) is also well posed.

Proof. If $Q(\cdot, t) \in C_{-\infty}^{\infty}, t \in[0, T]$, then $G(s, t, \tau) \in C_{-\infty}^{\infty}, t, \tau \in[0, T]$. Hence, $\widetilde{u}(s, t) \in C^{1}([0, T], S)$. The corollary is proved.

Theorem 2 For each symbol $A(t, \cdot) \in C_{-\infty}^{\infty}, t \in[0, T]$, there exists a function $B(t, \cdot) \in C_{-\infty}^{\infty}, t \in[0, T]$, such that problem (1), (2) is well-posed from $S$ to $C^{1}([0, T], S)$. 
Proof. Put

$$
B(t, s)=\exp \left(-i \operatorname{Im} \int_{0}^{t} A(\tau, s) d \tau\right)
$$

Then

$$
\Delta(s)=\int_{0}^{T} \exp \left(\operatorname{Re} \int_{0}^{t} A(\tau, s) d \tau\right) d t>0
$$

Let us show that

$$
Q(\cdot, t)=\frac{1}{\Delta(\cdot)} \exp \int_{0}^{t} A(\tau, \cdot) d \tau \in C_{-\infty}^{\infty}, \quad t \in[0, T] .
$$

Since $A \in C\left([0, T], C_{(l)}^{(k)}\right)$ for all $k$ and $l$, we can approximate $A$ by functions $A_{\varepsilon}$, $\varepsilon>0$, that are stepwise with respect to $t$ and obtain

$$
\left\|A(t, \cdot)-A_{0}(t, \cdot)\right\|_{(l)}^{(k)}<\varepsilon, t \in[0, T], \quad\left\|\int_{0}^{t} A(\tau, s) d \tau-\int_{0}^{t} A_{0}(\tau, s) d \tau\right\|_{(l)}^{(k)}<\varepsilon T .
$$

Thus we have reduced problem (1), (2) to the multi-point boundary-value problem in a multilayer

$$
\begin{gathered}
\frac{\partial u(x, t)}{\partial t}=A_{0}\left(t_{k}, \frac{\partial}{\partial x}\right) u(x, t), \quad t_{k} \leq t \leq t_{k+1}, \quad k=0,1, \ldots, N-1, \\
B_{0}\left(\frac{\partial}{\partial x}\right) u(x, 0)+B_{1}\left(\frac{\partial}{\partial x}\right) u\left(x, t_{1}\right)+\ldots+B_{N}\left(\frac{\partial}{\partial x}\right) u(x, T)=\varphi(x),
\end{gathered}
$$

where $B_{k}(x)=\exp \left(-i \int_{0}^{t_{k}} \operatorname{Im} A_{0}(\tau, s) d \tau\right)$. In [5], it was proved that the resolving function $Q^{*}$ of this boundary-value problem satisfies the conditions

$$
\left|Q^{*}(s, t)\right| \leq 1 \quad \text { and } \quad\left|\frac{\partial^{k} Q^{*}(s, t)}{\partial s^{k}}\right| \leq C_{k}(1+|s|)^{p_{k}}, \quad s \in \mathbb{R}^{n}, \tau \in[0, T],
$$

i.e., $Q^{*}(\cdot, t) \in C_{-\infty}^{\infty}, t \in[0, T]$. Therefore, $\left\|A(t, \cdot)-A_{0}(t, \cdot)\right\|_{(l)}^{(k)}<M \varepsilon, s \in \mathbb{R}^{n}$, $\tau \in[0, T]$, i.e., $Q(\cdot, t) \in C_{-\infty}^{\infty}, t \in[0, T]$. Thus this problem is well posed from $S$ to $C^{1}([0, T], S)$. The theorem is proved.

Corollary 1 yields the following corollary.

Corollary 2 Problem (3), (4) is also well posed from $C([0, T], S)$ to $C^{1}([0, T], S)$.

Example 1 Consider the equation

$$
\frac{\partial u(x, t)}{\partial t}=(2 t-T) \Delta u(x, t)+c(t) u(x, t), \quad x \in \mathbb{R}^{n}, t \in[0, T] .
$$

In [2], it was shown that there is no well-posed two-point boundary-value problem in $S$. Consider this equation under the integral boundary condition

$$
\int_{0}^{T} u(x, t) d t=\varphi(x), \quad x \in \mathbb{R}^{n}
$$


Then the boundary value condition is well posed from $S$ to $C^{1}([0, T], S)$, and

$$
Q(s, t)=\frac{\exp \left(\left(T t-t^{2}\right)|s|^{2}+\int_{0}^{t} c(\tau) d \tau\right)}{\int_{0}^{T} \exp \left(\left(T t-t^{2}\right)|s|^{2}+\int_{0}^{t} c(\tau) d \tau\right) d t}, \quad s \in \mathbb{R}^{n}, t \in[0, T] .
$$

is its resolving function. We use Laplace's method to estimate the denominator [8]. If $f(t)$ and $\sigma(t)$ are real-valued functions, $\sigma^{\prime \prime}\left(t_{0}\right)<0$, and $\sigma$ has a single maximum at the point $t_{0}$, then the asymptotic behavior of the function

$$
F(\lambda)=\int_{a}^{b} f(t) \exp (\lambda \sigma(t)) d t
$$

is following

$$
F(\lambda) \sim f\left(t_{0}\right) \exp \left(\lambda \sigma\left(t_{0}\right)\right) \sqrt{-\frac{2 \pi}{\lambda \sigma^{\prime \prime}\left(t_{0}\right)}} \text { as } \lambda \rightarrow+\infty
$$

Therefore,

$$
\Delta(s) \sim \frac{\sqrt{\pi}}{|s|} \exp \left(\int_{0}^{T / 2} c(t) d t\right) \exp \left(\frac{T^{2}|s|^{2}}{4}\right) \quad \text { as }|s| \rightarrow+\infty .
$$

Hence,

$$
Q(s, t) \sim \frac{|s|}{\sqrt{\pi}} \exp \left(\int_{T / 2}^{t} c(\tau) d \tau\right) \exp \left(-\left(t-\frac{T}{2}\right)^{2}|s|^{2}\right) \quad \text { as }|s| \rightarrow+\infty .
$$

Thus, $Q(\cdot, t) \in C_{-\infty}^{\infty}, t \in[0, T]$, and the problem is well posed from $S$ to $C^{1}([0, T], S)$.

Example 2 Consider the more general equation

$$
\frac{\partial u(x, t)}{\partial t}=a(t) \Delta u(x, t)+\sum_{k=1}^{n} b_{k}(t) \frac{\partial u(x, t)}{\partial x_{k}}+c(t) u(x, t), \quad x \in \mathbb{R}^{n}, t \in[0, T] .
$$

where $a(t), b_{k}(t), c(t)$ are real-valued functions continuous on $[0, T]$. Then by theorem 2 the boundary-value problem with the condition

$$
\int_{0}^{T} u\left(x_{1}-B_{1}(t), \ldots, x_{n}-B_{n}(t)\right) d t=\varphi(x), \quad x \in \mathbb{R}^{n},
$$

where $B_{k}(t)=\int_{0}^{t} b_{k}(\tau) d \tau, 1 \leq t \leq n$, is well posed from $S$ to $C^{1}([0, T], S)$.

\section{Conclusion}

It is proved that, for pseudo-differential time-dependent equations, well-posed boundary-value problems exist if the boundary conditions have an integral form. Some interesting examples of well-posed boundary-value problems are given. 


\section{REFERENCES}

1. B.J. Ptashnik. Nonlocal boundary value problems for partial differential equations, [ B. J. Ptashnik., V.S. Ilkiv, I.I. Kmit, V.M. Polishchuk]. 2002. K.: Scientific thought, $416 \mathrm{p}$.

2. A.A. Makarov. The existence of a correct two-point boundary value problem in a layer for systems of pseudo-differential equations, Differential Equations, 1994. - V.30, No.1. - P. 144-150.

3. A.A. Makarov. Parabolic boundary value problems for systems of pseudodifferential equations in an infinite layer, Differential Equations, 1996. - V.32, No.5. - P. 636-642.

4. L.V. Fardigola. On nonlocal two-point boundary value problems in a layer for equations with variable coefficients, Siberian Math. J., 1997. - V.38, No.2.P. 424-438.

5. A.A. Makarov, D.A. Levkin. Multipoint boundary value problem for pseudodifferential equations in multilayer, Visnyk of V.N.Karazin Kharkiv National University. Ser. "Mathematics, Applied Mathematics and Mechanics". - 2014. - No.1120. - P. 64-74.

6. L.R. Volevich, S.G. Gindikin. Distributions end convolution equations. 1994. M.: Science, 336 p.

7. M.A. Naimark. Linear differential operators. 1961. M.: Science, 528 p.

8. M.V. Fedoryuk. The saddle-point method. 1977. M.: Science, 366 p. 
Макаров О.А., Левкін Д.А. Крайова задача в шарі для еволюційних псевдодиференціальних рівнянь 3 інтегральною умовою. У даній роботі розглядається крайова задача для еволюційного псевдодіференціального рівняння з інтегральною умовою в просторі Л. Шварца. Ця задача є узагальненням двоточкової і багатоточкової крайових задач для диференціальних рівнянь в частинних похідних, які розглядалися раніше рядом авторів і для яких були отримані умови коректності в різних просторах функцій. Макаровим О.А. в попередніх роботах було доведено існування коректної двоточкової крайової задачі для будь-якого рівняння в частинних похідних зі сталими коефіцієнтами. Пізніше автори даної роботи узагальнили цей результат на багатоточкову крайову задачу в полішарі при додатковій умові трансмісії. Розглянута в цій роботі крайова задача під дією перетворення Фур'є по просторових змінних переходить в крайову задачу для звичайних диференціальних рівнянь, що залежать від параметрів. Отримано умови коректності вихідної крайової задачі в термінах оцінок на розв'язувальну функцію двоїстої задачі. Потім в роботі доводиться, що для будь-якого псевдодіференціального рівняння зазначеного типу існує коректна крайова задача з інтегральною умовою, яка визначається по символу псевдодіференціального оператора. Для цього використовується апроксимаційна крайова задача в полішарі, яка виходить при рівномірній апроксимації неперервного символу псевдодіференціального оператора кусково-постійним символом $з$ відповідною йому багатоточковою крайовою умовою. Така апроксимаційна крайова задача $є$ коректною в просторі Л. Шварца, а значить, і гранична крайова задача з інтегральною умовою також є коректною в цьому просторі. В роботі також наведені приклади таких коректних крайових задач.

Ключові слова: псевдодиференціальні рівняння; крайова задача; перетворення Фур'є, простір Шварца.

Article history: Received: 20 August 2018; Final form: 28 October 2018; Accepted: 29 October 2018. 